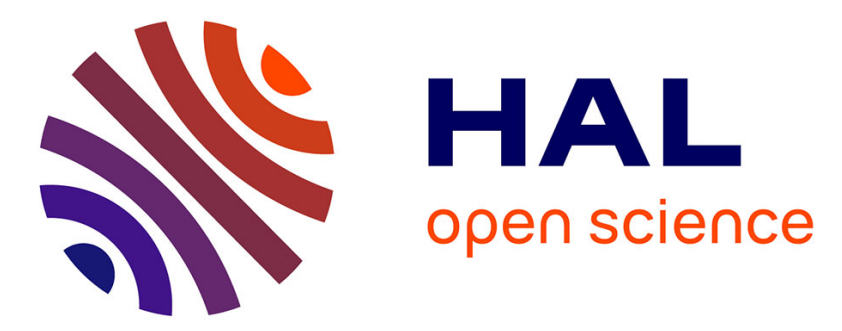

\title{
Supply Chain Organisation for Proximity Distribution: Comparison between French and Japanese Models
}

Claire Capo, Odile Chanut

\section{To cite this version:}

Claire Capo, Odile Chanut. Supply Chain Organisation for Proximity Distribution: Comparison between French and Japanese Models. Supply Chain Forum: An International Journal, 2015, 14 (3), pp.30 - 41. 10.1080/16258312.2013.11517319 . hal-01767007

\section{HAL Id: hal-01767007 https://hal.science/hal-01767007}

Submitted on 16 Apr 2018

HAL is a multi-disciplinary open access archive for the deposit and dissemination of scientific research documents, whether they are published or not. The documents may come from teaching and research institutions in France or abroad, or from public or private research centers.
L'archive ouverte pluridisciplinaire HAL, est destinée au dépôt et à la diffusion de documents scientifiques de niveau recherche, publiés ou non, émanant des établissements d'enseignement et de recherche français ou étrangers, des laboratoires publics ou privés. 


\title{
Supply Chain Organization for proximity distribution: Comparison between French and Japanese Models
}

\begin{abstract}
:
Convenience stores (CS) - or local stores - take different forms worldwide reflecting national market characteristics. In France, the mass retail sector is led by a few powerful retailing groups along directive lines. Power is more diffuse in Japan, with intermediaries playing a significant role and regulating the supply chains along more collaborative lines. Using a grid to analyse seven dimensions of proximity, we compare business models which include supply chain organisation for local store chain in Japan (so-called convenience stores) and in France (so-called proximity stores). What we identify is significant convergence amongst local store chain models relating to most of the aforementioned dimensions of proximity except for the inter-organisational proximity in which lies some major divergences.
\end{abstract}

Keywords: supply chain organisation; proximity; proximity stores; convenience stores, Japan, France.

Claire Capo Aix Marseille Université, CRET-LOG EA 881, France claire.capo@ univ-amu.fr Odile Chanut Aix Marseille Université, CRET-LOG EA 881, France odile.chanut@univamu.fr 


\section{Supply Chain Organization for proximity distribution: Comparison between French and Japanese Models}

Derived from so-called mom-and-pop family-run grocery stores, convenience stores (hereafter referred to as CS) first appeared in the United States in May 1929 with a chain called the Southern Ice Company, which alongside ice cream also sold fresh produce like bread, milk and eggs. Capitalising on their small size and extensive opening hours, CS began to crop up in urban and rural zones that were too small to attract supermarkets. Their development accelerated in the English-speaking world and Asia following the Second World War, thanks notably to an organisational preference for franchising. In Japan, CS evolved into a highly efficient model led by Seven Eleven ${ }^{1}$ and its direct competitors. In France, after decades marked by supermarket and hypermarket developments on the outskirts of urban agglomerations where land was cheaper, retailers have recently started returning to city centres, applying new concepts of proximity. These changes have taken place within a context of economic crisis, rising transportation costs and greater social awareness of sustainability.

At first glance, the French and Japanese distribution systems could not be more different. The French system is an oligopsony comprised of a few large retailers with the power to impose their rules on the distribution channel's other participants, which include a number of international companies, logistics service providers and agribusiness SMEs. In Japan, the retail trade relies on a multitude of actors ranging from mom-and-pop stores to CS (although a significant concentration trend has been observed here as well). Otherwise, wholesalers play a major role in Japan whereas in France they have been marginalised by retailers who have integrated wholesale and logistics functions ever since the 1970s-1980s.

\footnotetext{
${ }^{1}$ The name Seven Eleven is a direct reference to the fact that when the chain was first launched, its stores stayed open 16 hours (from 7 am to $11 \mathrm{pm}$ ). Called Seven \& I Holdings today.
} 
Both countries have followed different paths and developed their own specific business models. Yet they have also gradually converged around a certain number of distribution concepts. This text focuses on local store chains ${ }^{2}$ in an attempt to demonstrate some convergence between relevant business models in France and Japan, despite very different contexts and origins. More specifically, it provides a succinct presentation of noteworthy developments in the circumstances that have shaped retail distribution in both countries (1) before offering a precise definition of the specific elements constituting the local store chain business models and more specifically their supply chain organizations, mobilising towards this end a proximity analysis grid derived from literature in this field (2). The paper ends with a comparison of the French and Japanese models (3).

\section{The changing context of retail distribution in France and Japan}

A business model's development will largely depend on which actors are wielding the most influence in the sectors in question. In France and Japan, very distinct distribution structures have led to the emergence of distinct brokers exercising different kinds of leadership.

\section{Different distribution structures...}

Starting in the 1970s, French retail distribution began to be structured around hypermarkets, defined as large (up to $20,000 \mathrm{~m}^{2}$ ) retail outlets located on the outskirts of urban areas and embodying the concept of having "tout sous le même toit" ["everything under the same roof"]

\footnotetext{
${ }^{2}$ Local store chains will be used as a generic term; convenience stores in reference to the Japanese versions of this phenomenon; and magasins de proximite for the French equivalent (literally "proximity shops", which can be translated as corner shops or neighbourhood shops, although the term "proximity" evokes more than spatial distance alone). See the second section below.
} 
At the same time, the country experienced an unprecedented and unequalled process of concentration, so that today, in the year 2013, nine large food retailers share the national market. These include seven French companies (Carrefour, Casino, Auchan, Système U, Intermarché, Leclerc, Cora) and two Germans (Lidl and Aldi) who started to penetrate France in 1987 via their hard discount format. The trend towards concentration means that these groups have adopted multi-format, multi-banner and multi-channel approaches, exploiting a range of formats including large or medium-sized outlets; hypermarkets; supermarkets; minimarkets; and hard discount stores - all based on a variety of brands and channels (physical stores, virtual stores and, more recently, drive-ins). In addition, retailers here have decided to integrate logistics and wholesale functions, managing them directly or via logistics service providers. Their objective has been to achieve economies of scale and consolidate and rationalise flows while also controlling their supply chains and increasing their power when bargaining with producers (Paché and Colin, 2001). Just like in the UK, French Grocery retailers have become the channels captains and now control, organise and manage the supply chain from production to consumption (Sparks, 2010). Indeed, high performance supply capabilities in a corporate strategy have been a driver for market expansion and explain to a large extent the success of modern retailers (Abrahamsson and Rehme, 2010). This culminated in wholesalers' marginalisation.

City centres had become more or less deserted before this modern distribution system developed around large and medium-sized outlets. For a while, they were populated by pseudo- grocery stores that were little more than a fallback solution for (expensive) occasional purchases. This trend has reversed in recent years, however, with French retailing groups rushing to open new city centre outlets based on an urban proximity format. This has notably been the case for certain historic proximity actors (Casino, Carrefour, Francap, Monoprix), who have had truly impressive plans to open new outlets. The enabling factor was France's 
2008 Economic Modernisation Law, which eased the authorisations required for opening outlets with a sales floor space of 300 to $1,000 \mathrm{~m}^{2}$. This was followed by a diversification drive responding to the exhaustion of the traditional hypermarket model and translating consumers' desire to gradually reappropriate city centres. Hence the new "au coin de la rue" ["corner store"] concepts conveyed by chains such as Daily Monop', U Express, Casino Shopping, or else Chez Jean (founded by the Casino and Relay groups). Even retailers with little if any presence in the minimarket niche have joined the race, as witnessed by chains such as A 2 Pas (Auchan) or Intermarché Express. These new local stores are trying to intensify consumers' perception of the accessibility of a particular store or its products and services, in a way that is redolent of Japanese convenience stores (Capo \& Chanut, 2012).

In Japan, local neighbourhood distribution has been structured around the concept of convenience store, embodied in a dense network of small sales outlets located near the places where people live and work. Although modern supermarket concepts had already cropped up here in 1957 with Daiei, their development was hindered by the "relative lack of space, a legal environment that was not conducive to big stores and banks' conservatism" (Ribault, 2000). This explains why Japan had 41.9 stores for 10,000 people in 2000 , versus 14.3 in France (nearly 3 times fewer!), 12.9 in Great Britain and 7.3 in the United States (c.f. Distribution Economics Institute of Japan, 2000). In addition, distribution is characterised in Japan by retailers' high degree of atomisation, with the big distribution chains accounting since 2007 for less than $10 \%$ of total retail turnover in the country (METI, Japan's Ministry of Economy, Trade and Industry), reflecting their relative lesser bargaining power. Moreover, Japanese distribution is still largely structured around long-distance channels that rely first and foremost on wholesalers, i.e. intermediaries whose function consists of constantly purchasing and storing large quantities of domestically produced or imported goods (and sometimes incorporating a service activity) with a view towards being able to supply professional users 
(retailers, communities, etc.) on a regular basis). The key role that Japanese wholesalers play reflects their long history (Box 1). They carry significant economic weight today, generating total revenues of 371.865 billion yen (or around $€ 3.670$ billion) and accounting for $73 \%$ of all commercial sales in Japan (versus $27 \%$ for the retail trade). ${ }^{3}$ Working alongside the country's producers, they have often been the drivers of technological and conceptual innovation, explaining why they fulfil a broker's role within this channel.

\section{Box 1. Wholesalers as key actors in Japanese trade since the $12^{\text {th }}$ century}

In the Kamakura era (1192-1333), toimaru (organised merchants, as opposed to individual vendors) began taking responsibility for transporting the rice that was used at the time to pay taxes in Japan. This involved their both supervising rice paddy workers dispersed across distant sites, and administering warehouses. When the period came to an end, they moved into the merchandise transportation business. During the Edo era (1603-1868) - which is essential for understanding modern Japan insofar as it accounts for the genesis of many Japanese traditions - the wholesaler system assumed unprecedented importance thanks to the support of the state, which reinforced these actors' social and economic status and their power over producers and retailers (Kitchell, 1995). The 1868 Meiji restoration witnessed rapid growth in the supply of products as well as the appearance of a number of large organisations. Retailers also began to consolidate during this period, which saw the development of department stores and specialist outlets. Wholesalers started focusing on industrial activities while continuing to expand their power with help from government. The big trading houses that came out of this move turned into core actors in Japan's old zaibatsu organisations, which evolved after the war into keiretsus, or large corporate conglomerates interconnected by means of crossshareholding. Today there are six large keiretsus in Japan (called the "Big 6"), all of which are organised around a bank or (wholesale) trading house, the sogo shosha.

Since the crisis of the 1990s (when the financial bubble burst), retailers have grown progressively more powerful, in part because they are starting to control information (notably pertaining to consumer behaviour) but also because of their desire to rationalise logistics. In addition, supply-side operators have been undermined as a result of the changing habits of consumers who have become increasingly price-sensitive due to the crisis, causing management problems rooted in producers' over-segmentation of markets (Ribault, 2000). This has led to retailers increasing price pressure on producers and wholesalers while also

\footnotetext{
${ }^{3}$ To compare, French wholesale trade amounted to $€ 572$ billion in 2010.
} 
developing private brands positioned at a lower price than their national rivals. It remains that customers are relatively stable in brand loyalty terms, which explains in turn the difficulty that private brands have had in achieving a breakthrough. It is broadly against this backdrop that the concept of convenience chains has developed. Japanese convenience stores amounted to 47,801 points-of-sale in 2012. The biggest networks belonged to large distribution groups or were affiliated with them via cross-shareholding arrangements, meaning that the stores received a great deal of help in terms of responsiveness or setting up efficient support systems (Dablanc, 2009). In total, $84.1 \%$ of Japanese convenience stores' market share comes from five chains belonging to five giant Japanese distribution groups: Seven Eleven (Seven \& I. holdings), Lawson (Daiei), Family Mart (Itochu), Sunkus and Circle K (Uny) and Ministop (Aeon).

After noting the very different roles played by the parties fulfilling a broker's function in each country - retailers in France and wholesalers in Japan - we can now focus on how they exercise their leadership. 


\section{... Leading to the emergence of brokers exercising directive leadership in}

\section{France or collaborative leadership in Japan}

The configurations found in the mass retail sector and the kinds of leadership exercised here reflect a country's socio-cultural context. Some leaders tend to apply coercive forms of power and use their economic influence and bargaining power to weigh upon other actors in a way that is more directive than collaborative. They continue to operate under the aegis of a transactional exchange framework (directive leadership). Others mobilise their ability to get all of the different actors to work together by invoking relational norms that encourage participation. The framework of this exchange is more relational in nature, as per McNeil's sense of the term (1980). It seems much less clear here that the actors in question are behaving like leaders since they share a more diffuse kind of power with other players, in line with the collaborative leadership model (Bonet et al., 2013).

Because of their economic weight, the power of their procurement operations and their integration of logistics functions, the big French retailers wield extensive control over the inter-organisational relationships characterising their supply chains. As such, they benefit from significant bargaining power in their dealings with industrial suppliers, who can be either local (SMEs) or national or international companies. The same applies to their subcontractors, such as logistics service providers. Exchanges are mainly transactional in nature, although a few areas of cooperation still remain, such as private brands or trade marketing. The retailers' main areas of competitiveness are the density of their sales outlet networks, price, consumer credit and service quality. Towards this end, they will invest in capacities and constantly seek greater efficiency. Retailers rely on considerable financial resources and key competencies in areas like marketing, human resource management and 
logistics, their goal being to enhance their own bargaining power across the supply chain. This means that theirs is a directive leadership and that they define and impose transactional rules and conditions on their partners, despite state authorities' efforts to equalise actors' balance of power (Chanut, 2007).

Previous research has shown that wholesalers' role and position within Japanese supply chains are even more central to actors' coordination than it is in France (Capo, 2008, 2009). The characteristics of the Japanese context as well as wholesalers' resources and competencies make it possible to identify the presence of a collaborative kind of leadership. In turn, this can become a factor in increasing supply chain performance. Within a supply chain, wholesalers will play a central role based on their ability to create coordination between actors. For historical, cultural and contextual reasons and irrespective of the wholesalers' economic weight, their influence on other members of the chain constitutes more of an attempt to achieve coordination and participation than to be directive. Japanese wholesalers' resources vary depending on their size and scope of activity (national or regional), although it is generally the national wholesalers who intervene in mass retail. In addition to having their own human, material and financial resources, they can also rely on what their keiretsu provides along these lines (Box 1). In a context of economic and commercial crisis, wholesalers offer the supply chain a modicum of stability. As an intermediary for all aspects of the exchange, they play a dual role, serving both as a buffer and as a filter between partners. They affect the general terms of trade as well as actors' behaviour. Sheltering behind certain norms, they have no compunction about using them for their own purposes, increasing their power throughout the supply chain. For instance, where they act as an interface between producers and retailers' information systems, they generally avoid total transparency because they are trying to appropriate for themselves a number of 
resources and specific kinds of expertise that they can then turn into sources of power (French and Raven, 1959). It remains that the leadership exercised by a Japanese wholesaler stems mainly from its ability to coordinate the different actors found within the chain. Other actors (suppliers or retailers, depending on the circumstances) also possess their own not insignificant sources of power, meaning that they too take part in the decision-making (regarding the distinction between coordinating and emulating brokers, see Capo, 2008). Wholesalers partake in this leadership role.

Insert Table 1

Very divergent local store chain business models have taken shape in these diametrically opposed contexts. To identify them, we will use a grid analysing dimensions of proximity.

\section{Local store chain business models}

Business models can be defined as choices made by organisations seeking to generate income (Lecocq et al., 2006). They are comprised of resources and competencies; product and service offers plus activities pursued; income generated and expenditures incurred; and, lastly, positioning within the sector's value chain. Different terms are used to refer to local store chain business models in Japan and France. In the former, the expression "convenience stores" (CS) is widespread, whereas in France people talk about magasins de proximité (“corner shops"). The difference is not only semantic but also involves sales and strategy concepts that do not invoke the exact same dimensions of proximity. Specific local store chain 
business models are based on different dimensions of proximity: spatial ones of course, but also five other dimensions that have been identified in literature. All constitute areas of strategic choice for chains and their distinctive concepts.

\section{A business model based on six dimensions of proximity}

As a body of literature, proximity relies on a variety of disciplines, ranging from economics and geography to social psychology, sociology or management. This diversity of approaches combines with the variety of (industrial, commercial, inter-organisational and intraorganisational) fields where proximity research has been applied (Gomez et al., 2011). Proximity is a multi-dimensional construct (Pecqueur and Zimmermann, 2004: Rychen and Zimmermann, 2008) affected by actors' subjectivity (Le Blouch, 2001). Above and beyond its spatial aspects - which people still refer to as geographic or access proximity - researchers have identified a non-spatial element pertaining to the social and economic relationships between actors, either involving people interacting with one another or the ties between people and organisations (Torre and Rallet, 2005). Two kinds of logic are at work here: a belonging logic that refers to the existence of more or less direct and/or strong social connections and interactions between individuals or organisations; and a similarity logic, referring to the existence of a cognitive and material base that is common to the actors in question, along with the sharing of one and the same system of representations and beliefs (Bouba-Olga et al., 2008). This non-spatial proximity can be broken down into five dimensions: functional proximity, relational proximity, identity proximity, process proximity (Bergadaà and Del Bucchia, 2009) and inter-organisational proximity (Capo \& Chanut, 2013), explained in figure 1. 


\section{Insert Figure 1}

Inter-organisational proximity speaks to a distribution channel's organisation upstream from the consumer. It appears when close connections develop with the upstream side of the channel, enabling actors to work together to design top-quality routine products as well as a wide range of services making life easier for people living in the neighbourhood while optimising the organisation of logistics. Brokers' ability to create inter-organisational proximity with supply chain actors can, in this context, become a distinct competitive advantage.

\section{Dimensions of proximity as a strategic "area of choice” alongside price positioning}

Each of the six dimensions of proximity represents an "area of choice" that must be made when building a specific local store chain business model (cf. Figure 2). It is possible to finetune these choices by operationalizing each of the six dimensions of proximity that have been selected here (Capo \& Chanut, 2013). To shape a business model within an area of local stores, organisations must position themselves and therefore make strategic choices involving all of these proximity dimensions and the associated variables. This is done in conjunction with the chain's price positioning, which will be based on two possible strategies "Everyday Low Prices"; or "High Low". As such, it is the multitude of proximity dimension combinations that explains the variety of specific business models. 


\section{Insert Figure 2}

With convenience stores, for instance, the area of choice mainly revolves around spatial, functional and process concepts of proximity. Here, the notion of "convenience" has been largely covered in marketing and service economics research, appearing for the first time in the early 1920s as a way of defining staples that were easy to get (Copeland, 1923). It subsequently evolved to include products and services that enabled consumers to save time (i.e. microwave ovens or personal services). All in all, convenience has been a way to reduce non-monetary costs (time, energy and opportunity) caused by the consumption of a product or service. At the distribution level, access and functional proximities have had a direct influence on the convenience of the purchasing act. According to Berry et al. (2002), convenience is governed by the amount of effort and time that consumers are willing to devote to their purchases. Time is a rare and finite resource (Berry, 1979; Gross, 1987) and using it for purchasing basic consumer products can be perceived as a cost rather than as an investment (Anderson and Shugan, 1991).

Japanese's CS' business models are based on dense territorial coverage (spatial proximity), longer opening hours, being able to offer a large number of services, products that have been adapted to a store's particular catchment area and are convenient (pre-prepared or prepackaged dishes) (functional proximity) and the guarantee of freshness and quality (process proximity). In France, the drive-through format revolves around circulatory proximity (sites are situated on urban access roads) as well as functional proximity (making everything easy for customers, who can place orders 24 hours a day and collect the order when they want - 
without having to lose any time picking in-store). France's new proximity store concepts surf across a range of dimensions that can, for instance, be relational and identity in nature, as exemplified by Monoprix ( Capo \& Chanut, 2013). Beyond each chain’s specific positioning, it is also worth examining points of convergence and divergence between French and Japanese proximity business models.

\section{Convergences and divergences between French and Japanese}

\section{proximity business model}

Both countries have witnessed some fundamental trends, such as growing interest in sustainability, services or private brands. Moreover, companies from both have sought innovation paths where they might benchmark foreign systems. As a result, significant convergence can be identified in their local store chain business models in relation to most of the aforementioned dimensions of proximity (spatial, functional, relational, process and identity). Regarding inter-organisational proximity, however, some major divergences persist.

Spatial proximity: density of sales outlet networks and increase in circulatory proximity

The basic goal of local store chain investment strategies is to achieve maximum coverage of the places where people live or work. In both Japan and France, having a dense network of sales outlets is a constant objective, albeit one experienced differently in the two countries due to variations in urban population densities and the availability of space. Thus, the density of coverage is much greater in Japan's large cities, for instance, creating an ultra-competitive 
market where circulatory proximity always comes into the equation. In this context, spatial (and especially circulatory) proximity comprises a major competitive advantage.

In Japan, points-of-sale are not only built for reasons of maximum coverage but also as part of the search for a balance between very densely covered urban zones, on one hand, and suburban and rural zones, on the other. In cities, high potential zones like office districts defined by their concentration of high income white-collar workers were identified very early on (Yahagi and Kar, 2009). Transition zones near underground stations, train stations or large corporate premises have been defined by Seven Eleven as areas with a potential of 1,000 customers a day. In some Tokyo districts, a busy shopping street will feature one CS every 100-150 meters. This clearly means that consumers find it convenient to access these stores but there are also negative implications for customer loyalty. Stores built in residential neighbourhoods help to balance sales between daytime and evening (or weekend and weekday) shopping across the whole of a network. Japanese CS have also started to penetrate rural areas with stores situated alongside major roads and sometimes featuring large parking spaces to accommodate truck drivers. All in all, the catchment area covered by a Japanese CS corresponds more or less to five minutes walking in any direction in an urban setting, or five to ten minutes driving in the countryside. This dense coverage reinforces people's perception of metric, temporal and circulatory spatial proximity. It makes it easier to decide where to go and how to get there given that the store will be found "on the way" to the individual's home or place of work, the restaurants they visit, and so on.

The density of stores is lower in France since distribution in this country has been developed mainly via large and medium-sized stores located on the outskirts of urban agglomerations. However, very recently there has been the launch of new proximity concepts inspired by the 
concept of convenience (Casino Shopping, Daily Monop, Chez Jean, A 2 pas, etc.). Chains have been trying to densify their coverage of city centres and actively seeking new sites for new physical stores as well as drives-throughs. Although high potential zones have been largely exploited in the country's capital, this is less true in its other cities, where the race to open up new stores (and especially drive-throughs) was exceptionally intense in 2013. Some spaces, such as the inside of transportation network facilities (train stations, underground stations) have not yet been exploited to the same extent as in Japan (see construct of "ekinaka"4), although the SNCF French National Railways is currently deploying a store concession strategy in its stations.

\section{Functional proximity: French mass retail as a disciple of Japanese}

\section{distribution systems}

These recent changes have attested to French retail trade's moving from a concept based on the distribution of products to one highlighting the distribution of services. Japanese convenience stores have been trailblazers in this area, as witnessed by their attempts to minimise stocks and offer products and services adapted to customers' needs (Meyer-Ohle, 2003). To maximise the benefits perceived by customers, Japanese CS have often relied on stores being open $24 / 7$, staffed by employees working very flexible hours to avoid long queues at checkout stands (Ribault, 2000). Many of these outlets are laid out in a way that makes it easy for people to choose items quickly. A number even offer quiet reading spaces that tend to be located right next to the front window - an arrangement that has both a marketing purpose (helping pedestrians to see the store as a friendly place) and a security objective (dissuading potential shoplifters because they can be seen from the street). In

4 "Ekinaka" or literally "inside the train station" refers to areas with access limited to people who already have a ticket and where a number of convenience stores, bookstores, restaurants etc. have set up shop. 
France, on the other hand, new proximity concepts such as Casino Shopping are based on longer opening hours, friendly design, offering many ultra-fresh products, private brands and having many services. Several French retailers' narrative directly links proximity and product adaptation while emphasizing the extensive range of services on offer. One example is Casino when it highlights "the double meaning of proximity: geographic and service-related" (Casino, Activity report, 2010, p. 36). The drive-through is also a vector of convenience for customers. It saves time and energy insofar as the task of picking products is transferred to the distributor, who commits not to pass the cost on in the product price. It also makes it possible to decouple the moment when the order is given (for example, late in the evening) from when it is collected.

\section{Relational and identity proximity: franchising, a very popular organisation}

Franchising is a system where a contract ties a franchisor possessing a distinctive concept to its franchisees, independent traders and business owners who join the network to access its “commercial success system". Opting for this mode of organisation helps a network to expand rapidly under one and the same brand while enabling the requisite standardisation of store layouts and of the products and services being offered. Franchising favours relational and identity proximities with customers. A franchisee or an associate who has set up shop in a city centre becomes part of the local environment and will subsequently entertain relations with the customer base. Moreover, each store features its own characteristics reflecting the owner's personality and social roots. Unlike managers employed by company-owned outlets - and who regularly change their stores - franchisees own their company and tend to run the business for a long period, sometimes several decades, giving them the time to get close to a loyal and regular customer base. 
Either French and Japanese distribution groups have relied on these or ancillary contractual forms for their local store chains. This has been the case, for instance, with associated trade groups such as Système U, Intermarché or Leclerc, who have developed along cultural lines working together with independent traders and in conjunction with training schools. It also mainly applies to company-owned outlets players like Casino, with 4,000 of the company's 7,000 stores already being exploited on a franchise basis in 2010 (mainly through chains like Spar and Vival). Similarly, retailers in Japan have also chosen to build their CS networks mainly via franchising. Japanese CS are in fact mainly represented by the Japan Franchise Association and not by specialist CS trade associations, as is the case in the English-speaking world. The choice of franchisee partners usually involves traders with deep roots in the district where the store is being opened or acquired; who are well integrated into neighbourhood life and/or local trade associations; and who often have a license to sell alcohol. This makes it possible for the store's opening to be accepted by other local traders and ensures a core constituency of customers. Each Japanese CS is also likely to fulfil a hub function and sometimes serve as a "safety station". 5 As a result, the franchised organisation ends up favouring relational and identity proximities.

\section{Process proximity: private brands, a French practice that is widespread in}

\section{Japan today}

\footnotetext{
${ }^{5}$ According to a 2008 report by the Japan Franchise Association, out of 34,746 stores, 10,571 have already helped women in distress, 5,511 have taken care of lost, injured or abused children and 11,140 have provided assistance to elderly people
} 
Although the first private brands appeared in the $19^{\text {th }}$ century, it was Carrefour in France that modernised these "free" products in 1976 by turning them into one of its main competitive advantages. Since then, private brands' share of shelf space has risen constantly.

Private brands enable chains to consolidate process proximity. This is because they usually carry the brand of the chain and guarantee the retailer's control of product quality. They tend to be designed according to specifications that are "negotiated" with the suppliers manufacturing the private brands. In this way, the retailer controls both quality and traceability. Otherwise, although private brands (or wholesaler brands) arrived belatedly in Japan, they have also enabled a perfect control of quality and freshness in this country, both being attributes that consumers value above all others, especially for pre-prepared products bought in Japanese convenience stores.

Above and beyond process proximity, there is no doubt that private brands have an effect on all the other non-spatial dimensions of proximity. This explains their rising importance in new French proximity concepts. For example, private brands account for private brands account for half of all the items in the Casino Group's proximity format (interview with proximity branch marketing director by one of this article's authors, October 23, 2012). This is because they provide products that can be procured from a wide range of source and which, in traders' eyes, are distinctive from what other chains offer (functional proximity) enabling all the while a "good value for money" positioning compared to the national brands (price proximity) something that is crucial to any trader suffering from high overheads. They also enable the development of premium own brands conveying certain meanings and values (organic ranges, fair trade, local products, etc.) (identity proximity), in conjunction with discount or core private brands. In Japan, for instance, Natural Lawson - a specialist CS chain - offers private brands that are adapted to female and organic values. All in all, private brands constitute a 
vector where members of the supply chain can exchange knowledge about consumers' real and emerging needs (inter-organisational proximity).

\section{One major source of difference: inter-organisational proximity}

Inter-organisational proximity is based on distribution system structures and the interorganisational relationships that drive them. As demonstrated above, inter-organisational structures and relationships are very different in French and Japanese supply chains. This means that the main actors in inter-organisational proximity differ in terms of their nature and regulations.

There is no need at this point to revisit the considerable power and brokerage capabilities from which France's leading retailers have benefited as a result of their economic weight and control over wholesale trade and logistics. Nor is there any real need to take a second look at the role they play in designing private brand specifications, which intimates that they maintain close relationships with their manufacturers. The three key competencies of marketing, human resources and logistics (cf. leadership) have been largely exploited to configure interorganisational relationships within the supply chains. It is worth underlining the possible role that these factors do play in urban logistics, however, a topic that is particularly relevant to the concept of a city centre. With society's increasing awareness of the urgent need for sustainability, French retailing groups have been innovating and experimenting with urban logistics. Regular deliveries to downtown stores not only represent extra costs (10 to $30 \%$ higher than supermarkets) but also cause pollution and traffic congestion. For example, as home deliveries services are now booming, scenarios adopted by French e-grocery retailers are tested in order to measure the impact of logistics solutions (such as order-picking at a dedicated site called warehouse-picking or as in-store-picking) on overall distance in 
kilometres, the road occupancy rates in private car units and on GHG emission rates, in tons of equivalent CO2 (Durand and Gonzalez-Féliu, 2012). These measures help French Retailers to define the best logistics models. Others experiments have focused on creating solutions like the horizontal pooling of rival retailers or the use of multi-modal transportation. As an example, Monoprix has devised a system where it supplies stores in central Paris first via trains coming out of Le Havre, followed by trucks running on natural gas. Otherwise, Franprix (Casino Group) makes its deliveries into Paris via river transportation with barges coming down the Seine. These initiatives require the coordination of several stakeholders operating outside of the supply chain (SNCF Railways or the Paris Port Authority) and position the retailer as a broker operating extraneously to the traditional distribution channel. This makes inter-organisational proximity a key factor in the local store chain business model. The Japanese model, on the other hand, relies on wholesalers who serve as brokers organising the upstream distribution channel, as much with regards to the processing and dissemination of information as in terms of the channel's logistics and transactional organisation. This is particularly true for Japanese convenience stores, as illustrated by Mitsubishi-Shokuhin case (Box 2). Beyond this, the regular introduction of new products - something that is essential in Japan - is based on partnerships and the development of products that are exclusive to the CS, whether this involves private or national brands. To guarantee the freshness of prepared meals and other ready-to-consume products, CS chains and wholesalers have developed more or less advanced partnerships with producers, sharing with them information about consumer behaviour and co-developing a number of products and services.

Inter-organisational proximity can be seen in the wide range of partnerships linked to CS's Extensive service offer: all of the big convenience store chains have deals with mail-order firms in which orders can be filled through their stores. They also provide an alternative to credit cards, orders are made online, and order numbers are allocated before customers pay at 
the local convenience store. The product is subsequently delivered to the store (not the home), making it safer to pick up. These partnerships can be found all across France, with pickupand-go networks being located in urban and rural areas.

\section{Box 2. Illustration of wholesaler's broker role: Mitsubishi-Shokuhin}

Mitsubishi-Shokuhin is Japan's second-largest food wholesaler in revenue terms. It is a member of the Mitsubishi kereitsu (one of the "Big Six") and therefore enjoys direct technical, financial and human resource support from the group. This can translate, for instance, into a loan of industrial land; personalised design of the inventory management machines that are used in consolidation centres; or the possibility of relying on the conglomerate's affiliated transportation service providers.

As a wholesaler, Mitsubishi-Shokuhin presents itself as a "supplier of solutions" and intervenes at different levels. This starts with its commercial and transactional activities, where it manages relations with producers on retailers' behalf. One example is the key supply chain management role that it plays for the Aeon Group, Japan's second-largest retailer, which operates around 3,800 CS in the country under the Ministop brand. Although Aeon has also been able to establish direct relations with several suppliers - something that is rare for Japanese retailers - 70\% of its supplies still come from wholesalers. Otherwise, MitsubishiShokuhin is also working internally to develop wholesaler brands reflecting major trends and needs that it has identified. All of these brands will be offered in its customers' convenience stores. The company also gets involved in logistics, offering a wide range of services and positioning itself as a consolidation hub. It manages transportation service providers along with relations with other wholesalers in an attempt to homogenise actors' practices and create synergies to achieve higher quality service. It centralises orders from its franchisees' pointsof-sale to all of their different wholesalers, unpacks merchandise and prepares smaller crates that stores can then order on a per-unit basis. Its expertise ranges from the automated management of single item picking to equivalent manual activities. The best way to summarise this is to say that Mitsubishi-Shokuhin steers and consolidates the Aeon Group's downstream logistics, thanks to its logistics and relational expertise.

In the end, wholesalers ensure the stability of an organisation and its compliance with shared social and professional standards (Capo, 2009). They exercise a kind of social control that is more informal and less visible than the formal variant, thanks to the proximity they create between different members of the supply chain. By so doing, they facilitate interorganisational relationships while continuing to focus on the end user's needs. This is redolent, at the level of supply chains, of certain characteristics of Aoki's J firm (1995), a horizontal company that is more supple and flexible than the A firm, because of its social 
control mechanisms but also due to implicit contracts where incentivisation and trust drive efficiency and coordination.

\section{Conclusion}

Japanese and French retailers have long made different strategic choices with regards to sales formats. The Japanese model is CS, characterized by a dense network of stores located in living spaces. It is internationalised widely in the United States, Europe, and Asia. The French model, developed around suburban hypermarkets and supermarkets, is quite different. French retailers became aware that consumers today are looking for greater proximity to distribution locations. They therefore modernised their local store concepts and launched a new format, the drive-through, situated on convenient traffic axes that customers can easily access. All in all, the convergence between French and Japanese distribution business models basically appears to cover all proximity dimensions. The strategic choices governing these models manifest a significant amount of mimetic isomorphism (Di Maggio \& Powell, 1983). This mimetism is particularly relevant for the spatial and functional dimensions of proximity, which have become a core aspect of value creation for customers in 2014. As for the convergence around identity proximity, this has been fed by the global trend towards greater sustainability. In terms of inter-organisational proximity variables, supply chains' specificities exert significant influence and create divergence.

Supply chain organisations are based not only on different brokers but also on directive regulations, rationalised and relatively simple relationships (in France), or shared regulations and relatively complex exchanges between a multitude of actors (in Japan). Therefore, leadership and relationship control mechanisms are also divergent.This is the level in which business models are the hardest to transfer from one country to the next. The French model 
continues to be somewhat attractive to Japanese retailers seeking a more direct control of procurement (e.g., the

Aeon group) and pursuing two main objectives: lower costs and greater bargaining power. Similarly, French retailers are greatly interested in whatever is visible to downstream customers (products,services, etc.), hence in the Japanese model, insofar as it increases consumers' perceived level of convenience.

The convergence observed between the French and Japanese models of proximity retailing should be further investigated in other countries. Future research could address the possibility of global convergence, leading to a universal model of proximity retailing formats integrating the seven aforementioned dimensions of proximity.

\section{Bibliography}

Abrahamsson, M., Rehme, J. (2010), The role of logistics in retailers' corporate strategy-A driver for growth and customer value, Supply Chain Forum, An International Journal 11(4), $14-22$.

Anderson, E.W., Shugan, S.M. (1991), Repositioning for Changing Preferences: The Case of Beef versus Poultry, Journal of Consumer Research 18, 219-232.

Aoki M. (1995), The Japanese firm as a system of attributes: a survey and research agenda, Revue d'Economie Industrielle, Hors-Série, 83-108.

Bergadaà, M., Del Bucchia, C. (2009), La recherche de proximité par le client dans le secteur de la grande consommation alimentaire, Management \& Avenir 21, 121-135.

Berry, L.L. (1979), The Time-Buying Consumer, Journal of Retailing 55, 58-69.

Berry, L., Seiders, K., Grewal, D. (2002). Understanding service convenience, Journal of Marketing, 66(3), 1-17.

Bonet, D., Capo, C., \& Oliveira-Costa, L. (2013). Nature du leadership dans la supply chain de distribution: les cas du Brésil et du Japon. In N. Fabbe-Costes et G. Paché (éd.), La logistique, une approche innovante des organisations. Presse Universitaire de Provence, Aixen-Provence, 63-73.

Bouba-Olga, O., Carrincazeaux, C., Coris, M. (2008). La proximité, 15 ans déjà ! Avantpropos, Revue d'Economie Régionale et Urbaine 3, 279-287.

Capo, C. (2008). Les sources du pouvoir de l'intermédiaire: l'exemple du grossiste dans le canal de distribution japonais. 7èmes Rencontres Internationales de la Recherche en Logistique, Avignon (France).

Capo, C. (2009). Wholesalers operation management within distribution channels: Case studies in the Japanese context. 6th International Annual EurOMA Conference, Göteborg (Sweden), 14-17 June 2009. 
Capo, C., \& Chanut, O. (2012). Quand la proximité crée la convenience: une grille de lecture du système de distribution japonais. Cahiers Scientifique du Transport, 61, 91-117.

Capo, C., \& Chanut, O. (2013). Le concept de proximité comme source de différenciation: proposition d'une grille de lecture des positionnements voulus des distributeurs français. Logistique et Management, 21(1), 7-19.

Chanut, O. (2007). La loi Dutreil-Jacob, nouvel épisode de l'encadrement juridique des négociations tarifaires entre la grande distribution et le monde industriel, Décisions Marketing 47, 79-92.

Copeland, M. (1923), Relation of consumers' buying habits to marketing methods, Harvard Business Review 1(3), 282-289.

Dablanc, L. (2009), Le territoire urbain des konbini et des takkyubin au Japon, Flux 78, 6870.

Durand, B., Gonzalez-Feliu, J. (2012), Impacts of Proximity Deliveries on e-Grocery Trips, Supply Chain Forum, An International Journal 13(1), 10-19.

Di Maggio, P.J., Powell, W.W. (1983), The iron cage revisited: institutional isomorphism and collective rationality in organizational fields, American Sociological Review 48, 147-160.

Filser, M., Des Garets, V., Paché, G. (2012), La distribution, organisation et stratégie, Editions Management \& Société, Caen, 2nd ed.

French, J., Raven, B. (1959), The Bases of Social Power, in Cartwright D., Arbor A. (eds.), Studies in Social Power, University of Michigan Press, 150-167.

Gomez, P.-Y., Rousseau, A., Vandangeon-Derumez I. (2011), Distance et proximité : esquisse d'une problématique pour les organisations, Revue Française de Gestion 213, 13-23.

Gross, B.L. (1987), Time Scarcity: Interdisciplinary Perspectives and Implications for Consumer Behavior, in Sheth, J.N., Hirschman, E.C. (Eds), Research in Consumer Behavior, JAI Press, 1-54.

Kitchell, S. (1995), Tonya, the Japanese Wholesalers: Why their dominant position?, Journal of Macromarketing 15, 21.

Le Blouch, G. (2001), Approche systémique de la proximité: définition et discussion, Troisièmes journées de la proximité, Paris (France), 13-14 décembre.

Lecocq, X., Demil, B., Warnier, V. (2006), Le business model au cœur de la croissance de l'entreprise, Expansion Management Review 123, 96-109.

MacNeil, I.R. (1980), The new social contract: An inquiry into modern contractual relations, Yale University Press, Newhaven (CT).

Meyer-Ohle, H. (2003), Innovation and Dynamics in Japanese Retailing: From Techniques to formats to Systems, Palgrave MacMillan.

Paché, G., Colin, J. (2001), The Three Ages of Retail Logistics-Period Changes and Inventory Management, Supply Chain Forum, An International Journal 2(2), 58-67.

Pecqueur, B., Zimmermann, J. B. (2004), Economie de Proximités, Paris, Hermès, Lavoisier.

Ribault T. (2000), Les structures commerciales au japon: vers quelle modernisation ? Revue Française de Gestion, 16-30.

Rychen, F., Zimmermann, J.-B. (2008), Clusters in the global knowledge-based economy: knowledge gatekeepers and temporary proximity, Regional Studies 42(6), 767-776.

Sparks L. (2010), Supply chain management and retailing, Supply Chain Forum, An International Journal, 11(4), 4-12.

Torre, A., Rallet, A. (2005), Proximity and localization, Regional Studies 39(1), 47-60.

Yahagi, T., Kar, M. (2009), The process of international business model transfer in the SevenEleven group: US-Japan-China, Asia Pacific Business Review 15(1), 41-58 
Table 1. French retailers and Japanese wholesalers' leadership characteristics in their respective supply chains

\begin{tabular}{|c|c|c|}
\hline & \multicolumn{2}{|c|}{ Leadership } \\
\hline & Directive & Collaborative \\
\hline \multirow{2}{*}{$\begin{array}{c}\text { Country } \\
\text { Characteristics of the } \\
\text { mass food retailing }\end{array}$} & France & Japan \\
\hline & $\begin{array}{c}\text { Concentrated } \\
\text { Mature } \\
\text { Increasingly limited space }\end{array}$ & $\begin{array}{c}\text { Atomised } \\
\text { Mature } \\
\text { Very limited space }\end{array}$ \\
\hline $\begin{array}{c}\text { Supply chain's leading } \\
\text { actor }\end{array}$ & Retailers & Wholesalers \\
\hline $\begin{array}{c}\text { Resources and sources of } \\
\text { power }\end{array}$ & $\begin{array}{ll}\text { - } & \text { Economic weight } \\
\text { - Logistics infrastructure } \\
\text { (warehouses, procurement centres) } \\
\text { - Financial solidity } \\
\text { - Information system } \\
\text { - Abundant workforce }\end{array}$ & $\begin{array}{l}\text { - Logistics infrastructure (warehouses } \\
\text { and logistics zones) } \\
\text { - Financial solidity } \\
\text { - Abundant workforce } \\
\text { - Affiliation with other companies or } \\
\text { keiretsu }\end{array}$ \\
\hline \multirow[t]{2}{*}{ Competencies of leader } & $\begin{array}{l}\text { - } \\
\text { - Expertise in purchasing } \\
\text { (access, information, forecasting) } \\
\text { - Expertise in sourcing } \\
\text { - } \quad \text { Human resource training }\end{array}$ & $\begin{array}{l}\text { Expertise in coordinating logistics } \\
\text { flows and supply chain actors } \\
\text { - Management of informational flows } \\
\text { (before and during negotiations, } \\
\text { during exchanges and in anticipation } \\
\text { of future exchanges). } \\
\text { - Ability to reassure: relational } \\
\text { stability (relational norms) and } \\
\text { financial stability (guarantee) }\end{array}$ \\
\hline & - Mainly transactional & - Mainly relational \\
\hline
\end{tabular}

Source: taken from Bonet, Capo and Oliveira-Costa, 2013 


\section{Figure 1. The six dimensions of proximity used in a French retail context}

\begin{tabular}{|l|}
\hline Inter-organizational proximity \\
\hline \hline Setting up partnerships with retailers and \\
upstream and downstream supply chain actors \\
(private brand manufacturers, local suppliers, \\
franchisees or associates) to improve control \\
of assortments and logistics \\
\hline
\end{tabular}

\section{Process proximitv}

Development of product offer perceived by consumers as offering good quality an guaranteed by the manufacturing process' traceability. Private brands' share and the existence of short distances between production and distribution sites are also part of process proximity.

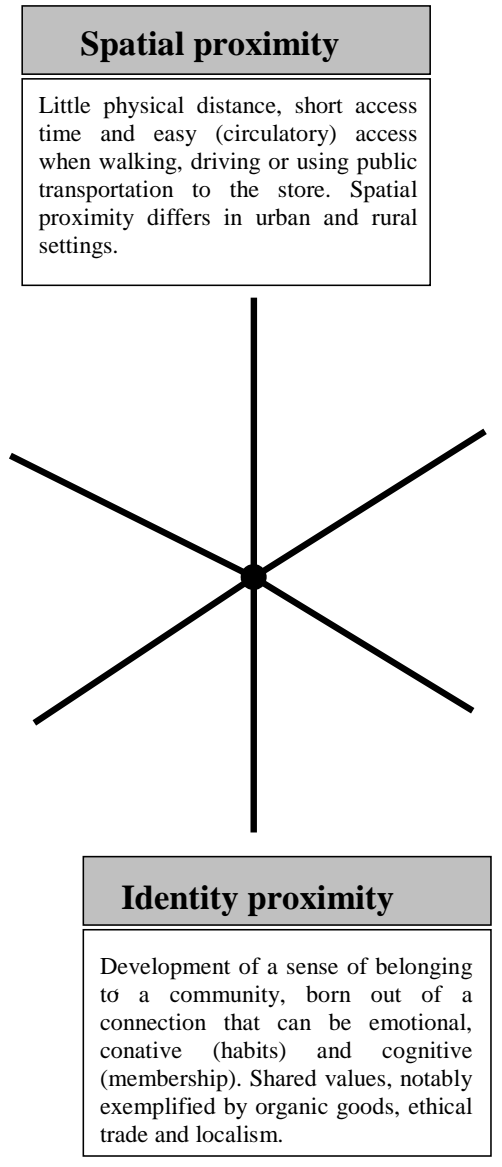

\section{Functional proximity}

Two orientations: a "supply" orientation where products are customized and readily available at the store; and a "convenience" orientation with long opening hours and a number of services on offer.

\section{Relational proximity}

Development of feelings of trust and affection between trader and consumer: based on number of employees; their level of comfort in dealing with customers or offering advice; and the use of relational ICT. 
Figure 2. Strategic areas of choice in the constitution of local store chain business models

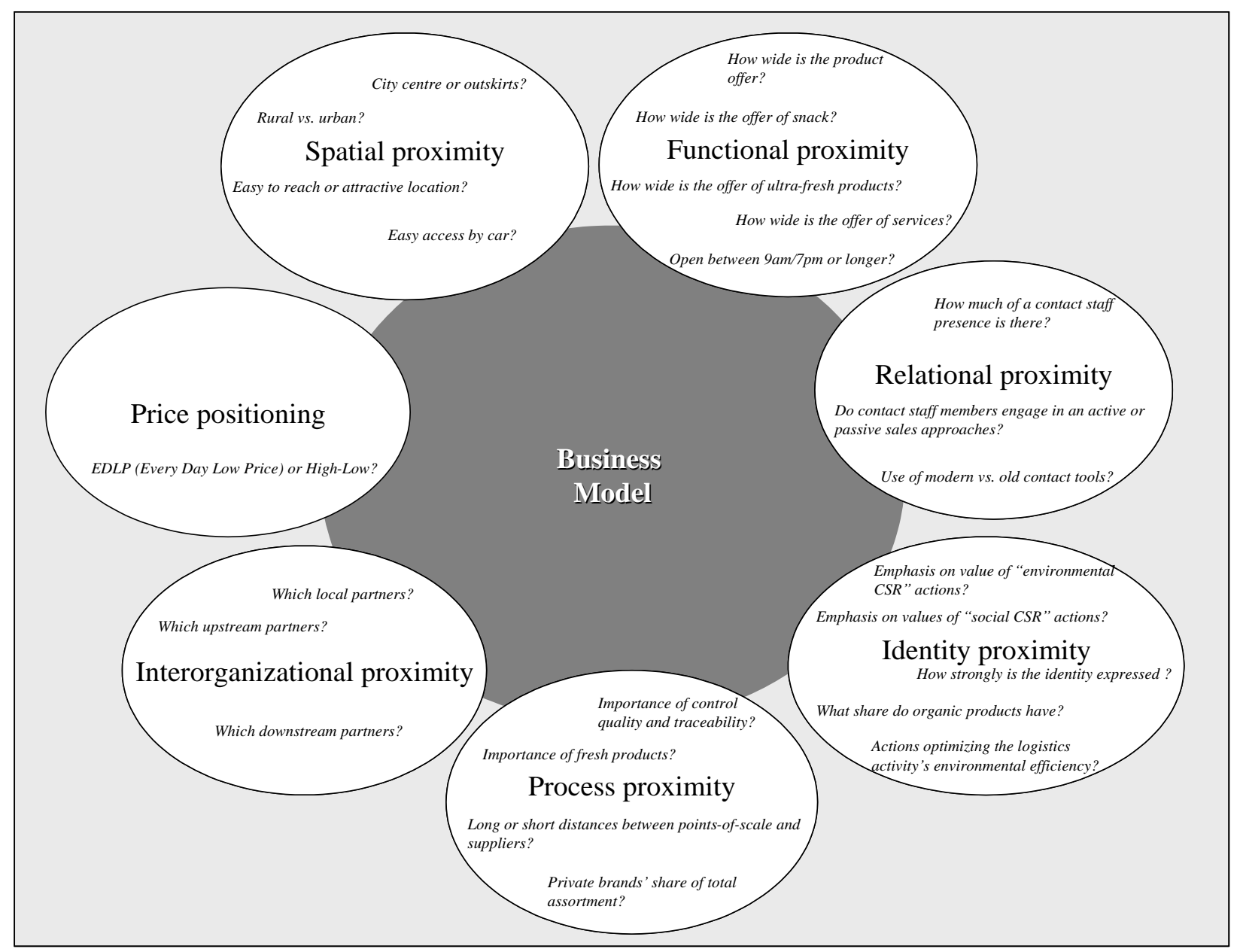

